\title{
Introduction to the Public Sector Economics 2017 Conference Issue - \\ Public investment: catalyst for sustainable growth
}

KATARINA OTT, Ph.D.

DUBRAVKO MIHALJEK, Ph.D.

Editors' introduction

https://doi.org/10.3326/pse.42.2.1

Katarina OTT

Institute of Public Finance, Smičiklasova 21, 10000 Zagreb, Croatia

e-mail : kott@ijf.hr

ORCiD: 0000-0003-2242-4181

Dubravko MIHALJEK

Bank for International Settlements, Centralbahnplatz 2, 4051 Basel, Switzerland e-mail: Dubravko.Mihaljek@bis.org ORCiD: 0000-0003-4706-9534 
The Institute of Public Finance, publisher of the journal Public Sector Economics, together with the Friedrich Ebert Stiftung, organized its annual conference in Zagreb on 3 November 2017. The main theme of the conference was the role of public investment in sustaining post-crisis growth, and the implications of this role for public finances in countries around the world.

The recovery from the global financial crisis had until 2016 been relatively modest and uneven, led mainly by private consumption. Business fixed investment and productivity growth had been weak and inflation low despite unprecedented monetary stimulus and historically low short- and long-term interest rates in major advanced economies. At the same time, infrastructure needs were sizeable, not least because post-crisis fiscal consolidation had significantly lowered public capital spending ratios. These conditions provided a unique opportunity to increase productive public spending: by locking in low interest rates with long-maturity borrowing, well-targeted spending on education, health or research and development, significant output gains could be obtained in the long run. In such a situation, one could expect additional public investment to generate relatively high rates of return, after allowing for risk, provided that good project governance was in place.

Against this background, many international fora recommended an increase in public investment to support demand and employment in the short run, and catalyze private investment and growth-enhancing innovations in the long run. That said, there were also questions about the ability of governments to identify and implement large-scale investment projects, as well as doubts about the size of public investment multipliers and long-term returns on public capital in a world of diminishing productivity growth, not to mention the impact of higher public investment on debt sustainability.

\section{ABOUT THE CONFERENCE}

Program committee members - Dubravko Mihaljek (Bank for International Settlements), Daniel Diaz-Fuentes (University of Cantabria), Peter Sanfey (European Bank for Reconstruction and Development), Atanas Kolev (European Investment Bank) and Josip Franić (Institute of Public Finance) - selected about twenty submissions, of which fifteen were presented at the conference. Presenters were researchers and policy experts from across the world. The five sessions covered the topics of public infrastructure and investment; lending, debt and growth; country-specific issues in investment and corporate growth; sectoral investment; and budget performance and transparency.

Keynote lectures were delivered by Balázs Égert (OECD), Evžen Kočenda (Charles University Prague, Institute of Economic Studies) and Matthias KollatzAhnen (the City Government of Berlin). Several policymakers and members of the business community provided introductory remarks to the conference: Zdravko Marić, Finance Minister of the Republic of Croatia; Manica Hauptman, Econom- 
ic Adviser in the European Commission Representation in Croatia; and Zrinka

Živković Matijević, Head of Research for Raiffeisenbank Austria's operations in Croatia.

The conference was supported by the European Commission Representation in the Republic of Croatia, Croatian Bank for Reconstruction and Development, HEP Group, Raiffeisenbank Austria, and Zagrebačka banka.

\section{WHAT IS IN THIS ISSUE?}

This conference issue of Public Sector Economics contains a selection of keynote speeches, introductory remarks, and research papers presented at the conference. Balázs Égert takes stock of the major policy drivers of business investment, which has been unusually weak in many advanced economies following the recent crisis. He identifies four policy areas that could help underpin business investment in the recovery phase: (i) better access to finance for firms, especially small and innovative businesses, through both banks and capital markets; (ii) simplification of corporate tax systems and a reduction in high corporate tax rates; (iii) a pro-competitive product market regulation; and (iv) lowering high regulatory uncertainty by, for example, designing and keeping transparent regulations.

Evžen Kočenda examines links between public investment, banking and sovereign risk. His work on the nexus between sovereign risk and banking sector characteristics in the EU suggests that less efficient and larger banking sectors are linked to higher sovereign risk, while higher foreign bank penetration and higher competition - two signs of diversified banking sectors - are associated with lower sovereign risk after the global financial crisis. There are two key implication for public finances. First, market participants now view the size of banking sectors as an upper bound for potential bailouts, which reduces fiscal space for public investment in a downturn. Second, lower creditworthiness of governments may negatively affect not only public but also private investment.

Zdravko Marić, Croatian Finance Minister, reviews the evolution of private and public investment in Croatia over the past fifteen years, and identifies headwinds and tailwinds for their pick-up in the medium term. Total fixed investment peaked at $28 \%$ of GDP in 2008; after the start of the crisis, it rapidly declined to less than $20 \%$. Public investment peaked at about $6 \%$ of GDP pre-crisis, but was cut to just around $3.5 \%$ in 2006-2010. In many ways, the pre-crisis level and structure of investment, biased toward housing and infrastructure, could not have been sustained, so adjustment was unavoidable given the need for fiscal consolidation and public sector deleveraging. Recent trends show improvement, with the bulk of new investment taking place in manufacturing, tourism and, within different investment goods, in machinery, equipment and intellectual property rights. The ongoing fiscal consolidation will remain a major constraint on public investment in the period ahead, but the authorities are also trying to reduce the tax burden and improve the investment climate. 
Matthias Kollatz-Ahnen and Markus J. Roick present their views on the global shortfall in infrastructure investment, particularly the gap in public investment at the municipal level in Europe. They claim that despite substantial interest of the private sector, funding shortages continue to be a major - though not the only bottleneck for raising investment. Using the example of Berlin, they evaluate several options for financing urban infrastructure, including improving tax collection, altering the composition of the city budget, imposing user fees for public services and mobilizing private capital for public investment projects.

Manica Hauptman warns that despite the return of more favourable financing conditions, investment in EU has not reached its pre-crisis levels. Some of the EU policy initiatives supporting national and EU public investment have already shown concrete and positive results. However, the EU is also finding out that it is important to give enough technical support to member states to create and manage their own projects. Another catalyst for public investment is a supportive regulatory environment, a theme echoed in many presentations at the conference.

Zrinka Živković Matijević emphasizes the importance of human capital investment in Croatia. Despite numerous attempts to improve the educational system and make the labour market more responsive to changing economic conditions, the Croatian education system remains poorly equipped to cope with the challenges of digital technology and a modern economy. This is the case not only with the public education system, but even more so with continuous learning and skills development in both public and private corporate sectors.

Ehtisham Ahmad, Annalisa Vinella and Kezhou Xiao examine the "how" of investment for sustainable development, focusing on public-private partnerships (PPPs) as a vehicle for pooling financial and management resources in the planning and implementation of infrastructure projects. They highlight interactions of investment decisions with tax policy options, institutional arrangements, and information flows. These interactions influence incentives facing firms, households and governments at different levels. To be successful, PPPs require public finance management arrangements such as the recording of public liabilities (including those of subnational governments and state-owned enterprises) in general government balance sheets. Without full information on the nature, generation and time-profile of liabilities, PPPs can easily become opportunities to "kick the fiscal can down the road", and create opportunities for game-play among the different levels of government, and among the private and public partners. Ahmad, Vinella and Xiao also study the choice between alternative contractual arrangements at different stages of a project's life cycle, noting that information asymmetry makes it possible for the private partner to extract extra rents, and for local governments to hide liabilities. This makes PPP contracts highly complex, and provides an opportunity for multilateral development banks with expertise in this area to assist emerging market economies in the design of such contracts. 
Sanja Borkovic and Peter Tabak from the European Bank for Reconstruction and Development investigate the relationship between public investment and productivity of Croatian firms. On a sample of some 48,000 firms over 2007-2015 they find that government investment in general has a significant positive effect on total factor productivity growth of private companies, but not on that of stateowned enterprises. Public investment in transport infrastructure tends to enhance productivity growth throughout the economy; public R\&D investment has the most significant effect on productivity growth of manufacturing companies, while productivity effects of public human capital investment seem to be largest for tourism firms. Borkovic and Tabak also find that public investment affects productivity with long lags, in transport and human capital formation, for instance, after four to five years.

Gökçen Yilmaz, from the School of Economics, Sinop University, studies how the allocation of public investment affected productivity growth in Turkey in 19752001. Her work highlights the importance of considering the sectoral breakdown of public investment when assessing its efficiency: shifting investment from transportation and communication to education, health care, city infrastructure, and security and energy infrastructure contributed positively to real productivity growth in Turkey. This finding implies that the government overinvested in transportation and communication services, and underinvested in the latter sectors, notably public energy infrastructure. In other words, public policy could have achieved a higher growth rate simply by reallocating investment resources across sectors.

Maria Manuel Campos and Hugo Reis, from Banco de Portugal, study the evolution of private returns to schooling in the Portuguese economy during 1986-2013. Using a matched employer-employee dataset that allows the tracing of individuals across time, they find the returns to schooling to be high, particularly for women, and to be the highest for tertiary education. As investment in lower schooling levels increases the returns to subsequent ones, while the government faces a budget constraint, the challenge for policymakers is to ensure the quality of public school system while providing low-income households access to tertiary level education. Given that private returns to tertiary education are high while social returns are lower relative to those for primary and secondary education, the findings of Campos and Reis also suggest that public policy needs to find some way to increase individual participation in financing of tertiary education.

These articles represent a selection of papers presented at the Conference; several more are expected to appear in subsequent issues of the Journal.

The issue ends with a review of Jean Tirole's landmark book "Economics for the Common Good". 